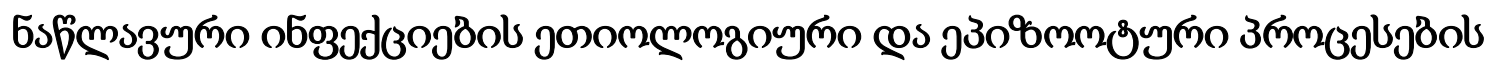

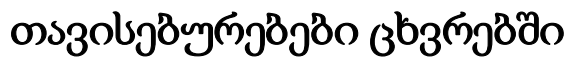

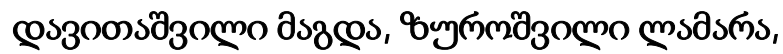

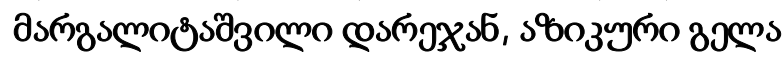 \\ os 3 ma z

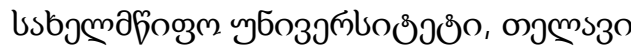 \\ https://doi.org/10.52340/idw.2021.489
}

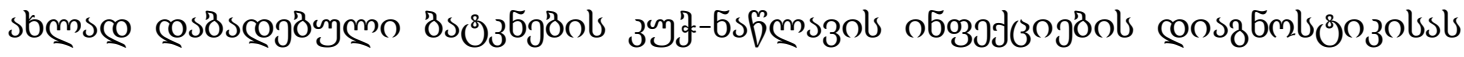

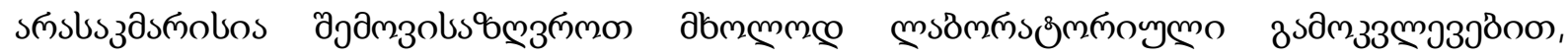

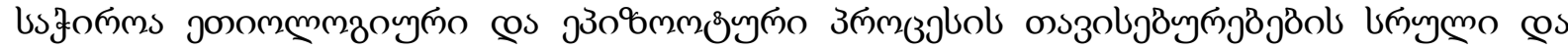

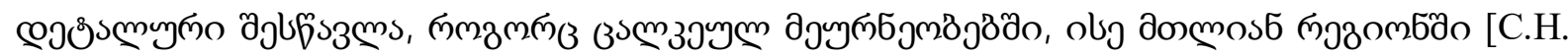
Латышев, 2009; К.Б. Бияшев, Б.К. Бияшев, А.Ж. Макбуз, Ж.С. Киркимбаева, 2012, Р. Ј. Quinn, B. K. Markey, F. C. Leonard, P. Hartigan, S. Fanning, E. S. Fitzpatrick, 2011].

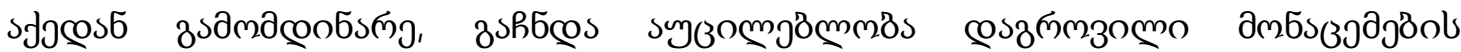

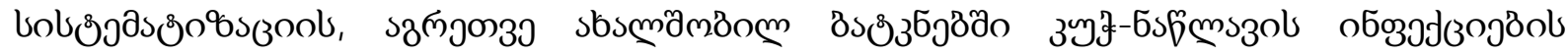

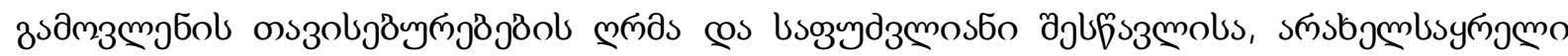

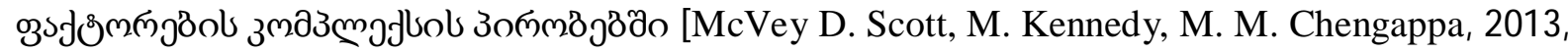
A.A. Zhakupova, K.B. Biyashev, B.K. Biyashev, S.E. Ermagambetova, G.M. Nurgozhayeva, 2017].

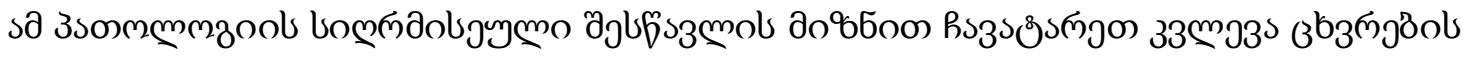

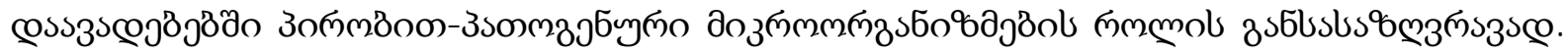

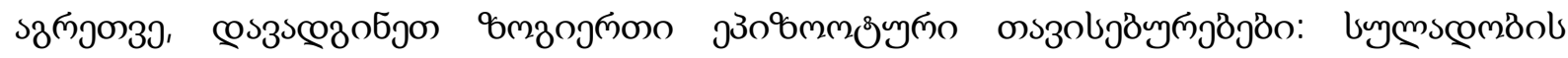

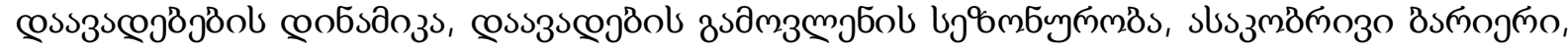

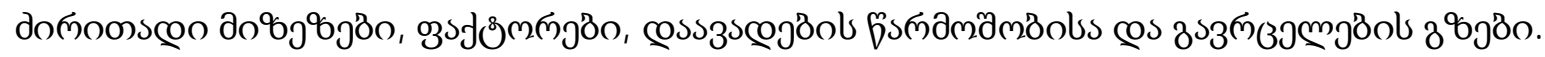

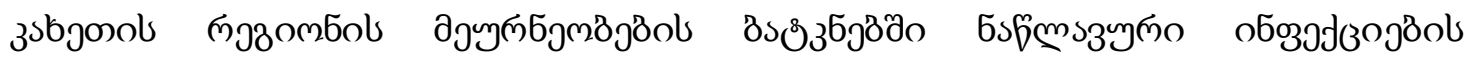

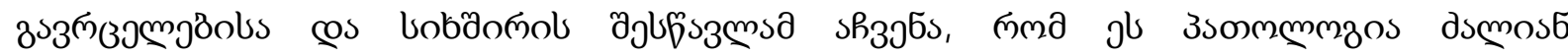

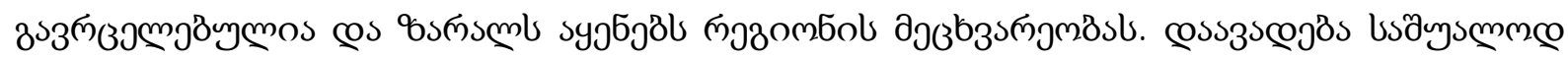

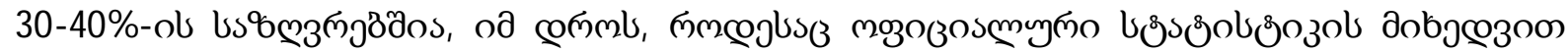

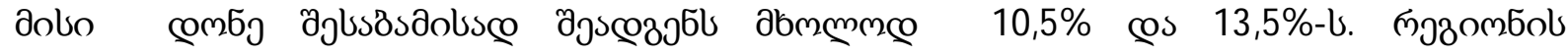

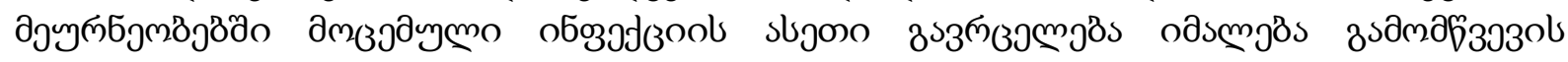

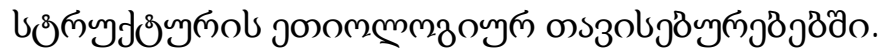

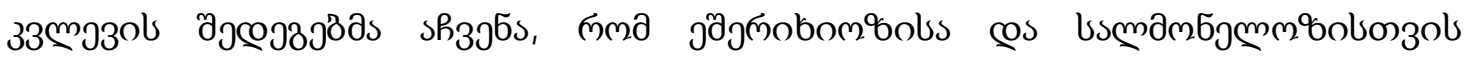

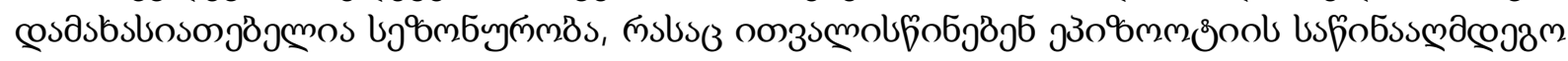

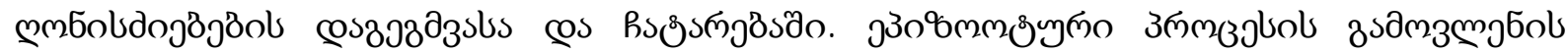

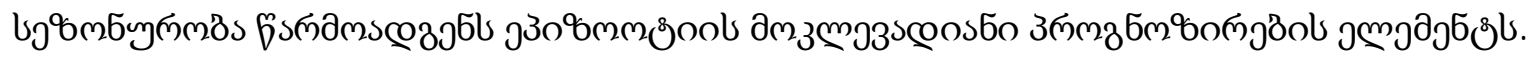

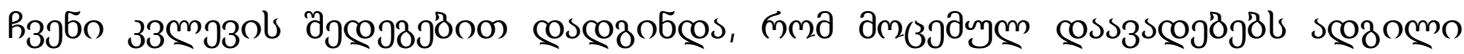

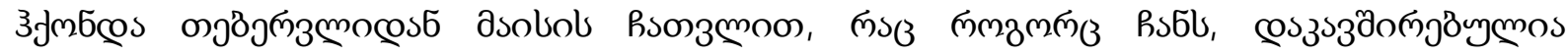

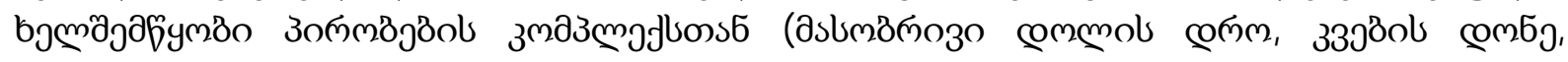

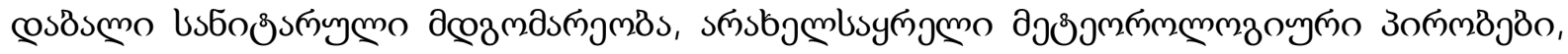

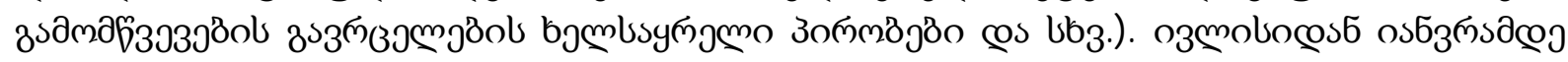




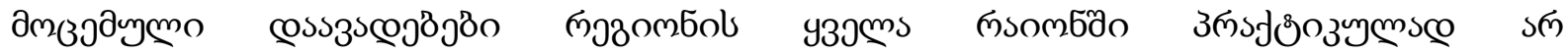

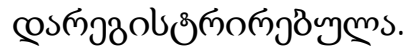

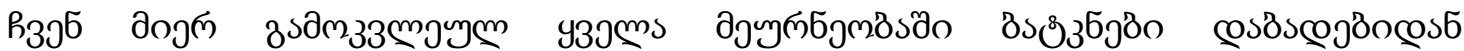

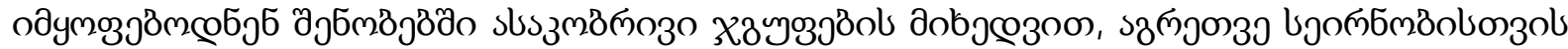

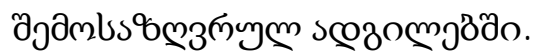

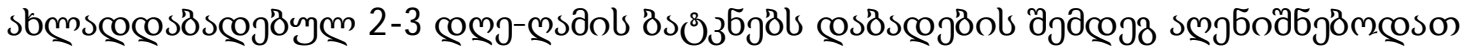

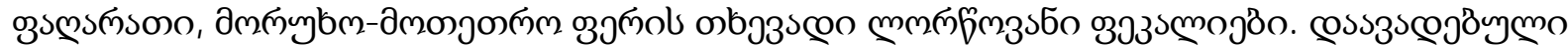

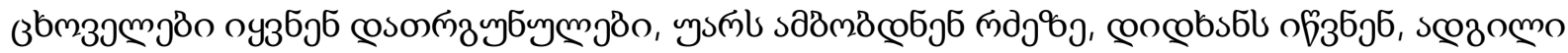

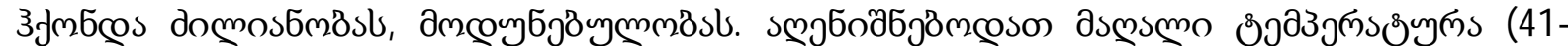

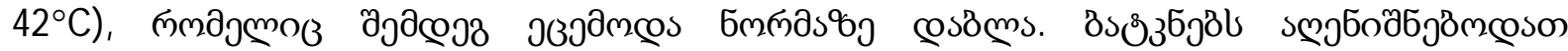

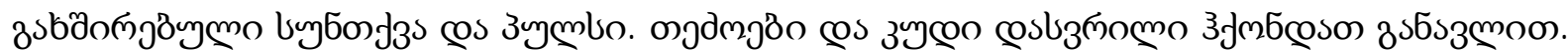

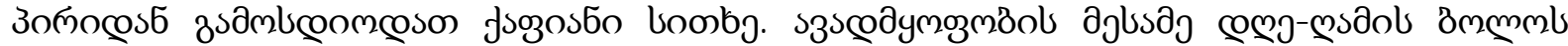

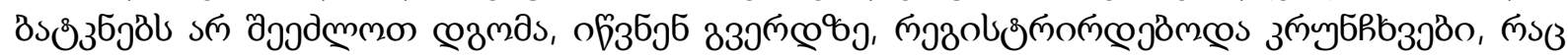

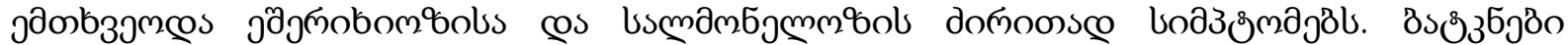

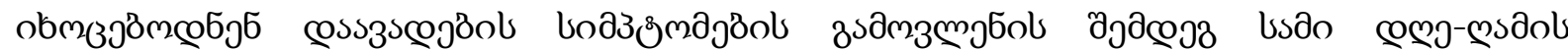
зьбдззммдे

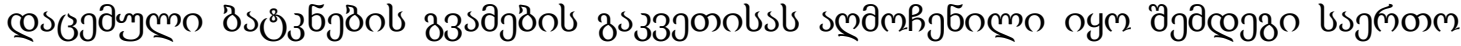

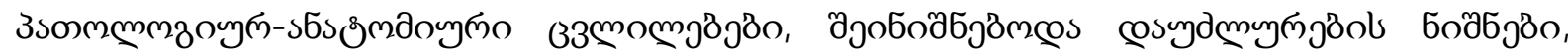

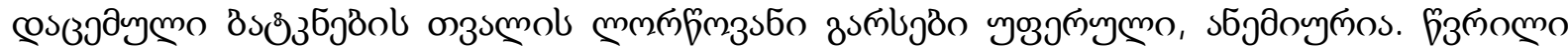

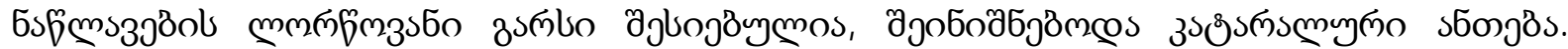

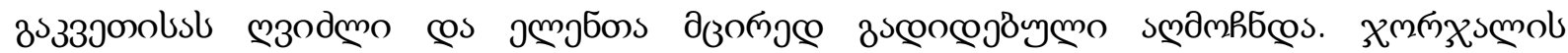

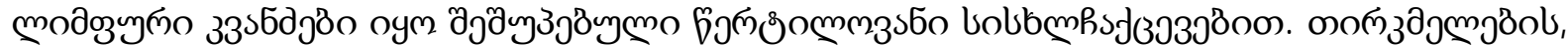

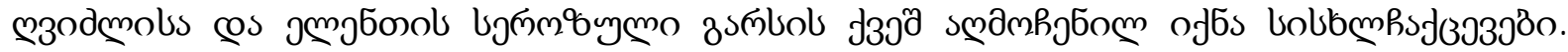

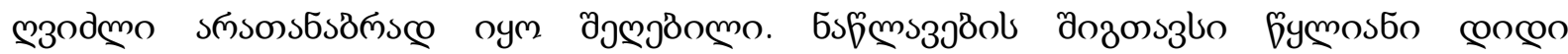

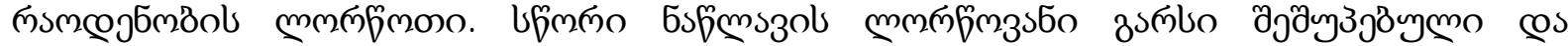

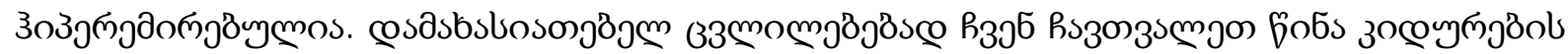

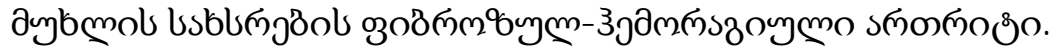

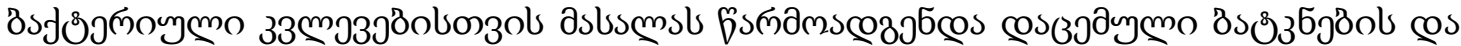

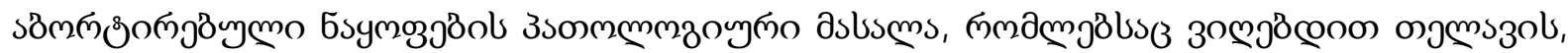

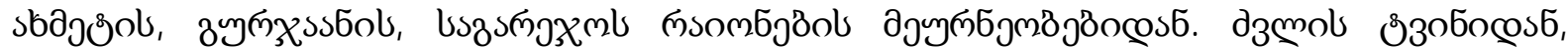

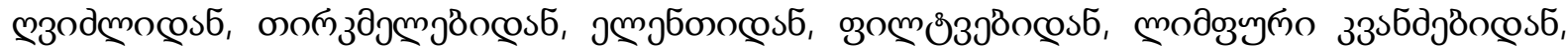

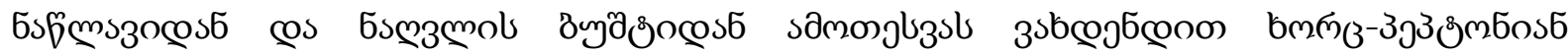

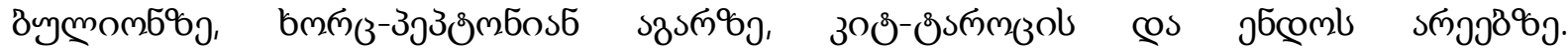

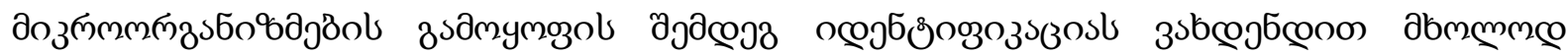

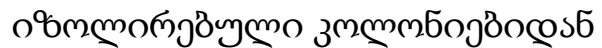

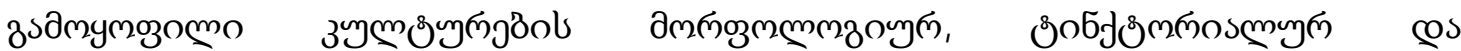

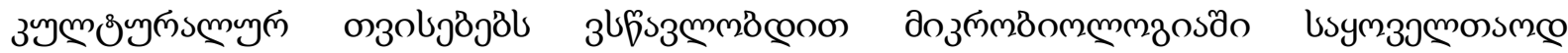

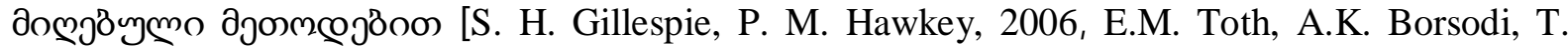
Felfoldi, B. Vajna, R. Sipos and K. Marialigeti, 2013, K. Abbott, Ph. Hynd, S. Graaf, T. Leahy, J.

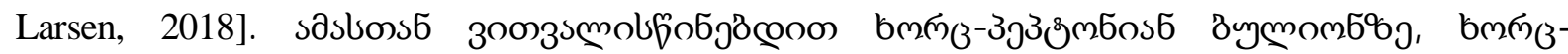

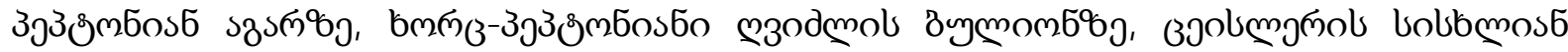

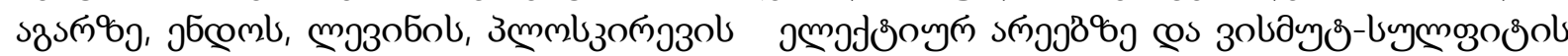

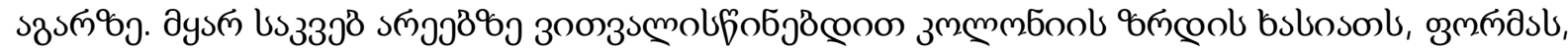

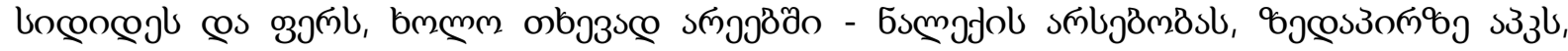

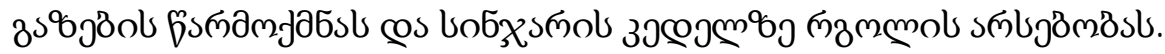




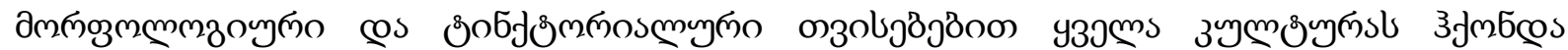

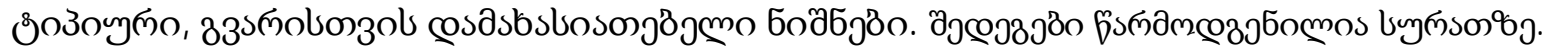

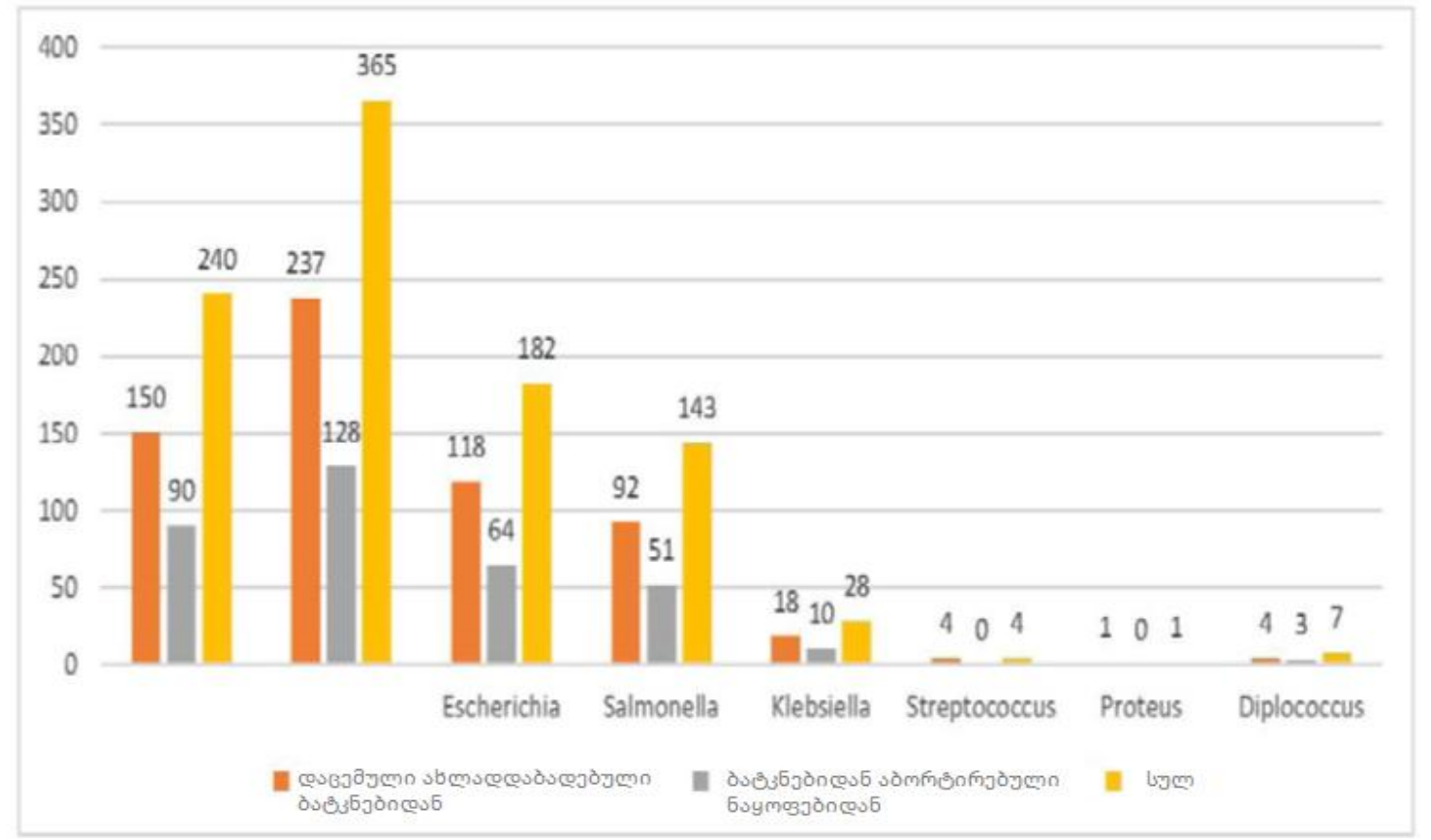

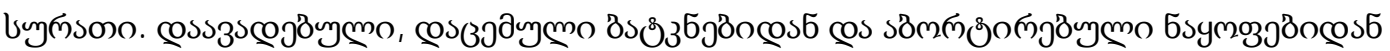

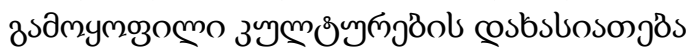

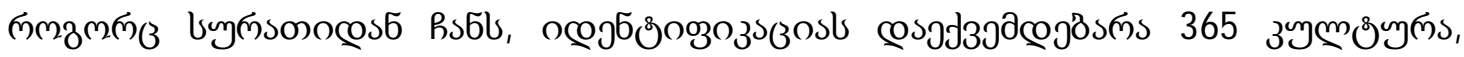

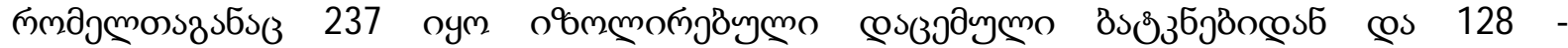

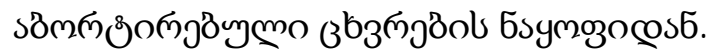

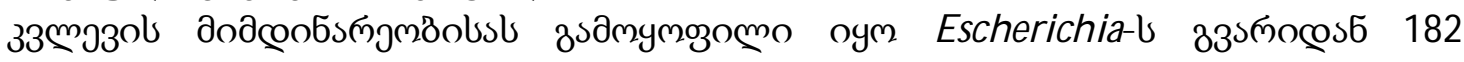

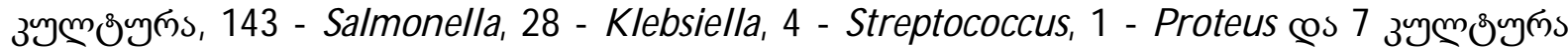

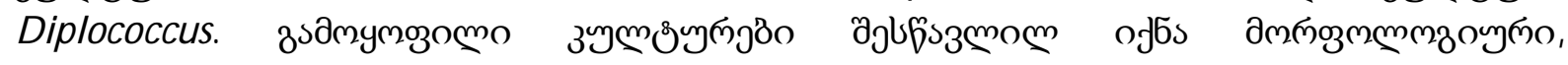

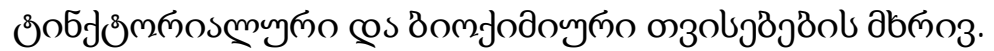

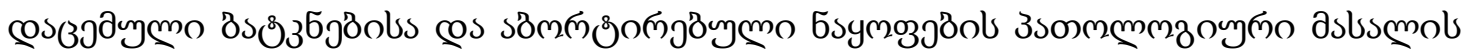

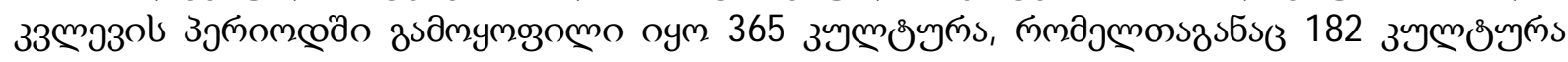

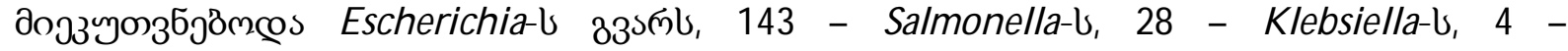

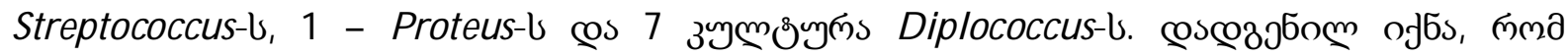
Вs

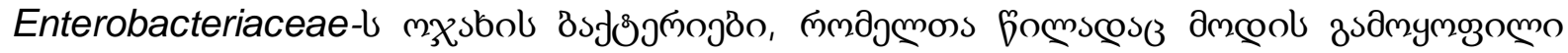

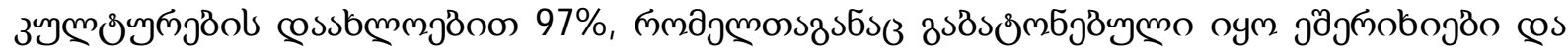

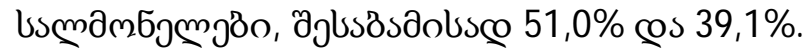

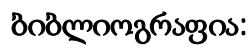

1. Бияшев К.Б., Бияшев, Б.К., Макбуз, А.Ж., Киркимбаева, Ж.С. (2012). Определение продолжительности персистенции бактерицинпродуцирующих штаммов в кишечнике ягнят. Вестник сельскохозяйственной науки Казахстана. №7, с. 55-57.

2. Латышев С.Н. (2009). Особенности эпизоотического процесса сальмонеллеза и эшерихиоза ягнят. Автореферат. Ставрополь. 
3. Gillespie, S. H., Hawkey, P. M. (2006). Principles and Practice of Clinical Bacteriology. Second Edition. England. John Wiley \& Sons Ltd.

4. Kym Abbott, Philip Hynd, Simon de Graaf, Tamara Leahy, John Larsen. (2018). The Practice of Sheep Veterinary Medicine. University of Adelaide Press.

5. McVey D. Scott, Melissa Kennedy, M. M. Chengappa. (2013). Veterinary Microbiology. 3rd edition. W ileyBlackwell.

6. Quinn P. J., Markey B. K., Leonard F. C., Hartigan P., Fanning S., Fitzpatrick E. S. (2011). Veterinary Microbiology and Microbial Disease. Second edition. W iley-Blackwell.

7. Toth E.M., Borsodi A.K., Felfoldi T., Vajna B., Sipos R. and Marialigeti K. (2013). Practical Microbiology.

8. Zhakupova A.A., Biyashev K.B., Biyashev B.K., Ermagambetova S.E., Nurgozhayeva G.M. (2017). Performance Test of the Drug «Enterocol». Journal of Pharmaceutical Sciences and Research. v. 9, №10, p.1941-1942.

\title{
Etiological and Epizootic Peculiarities Gastrointestinal Infection Processes in Sheep
}

\author{
Davitashvili Magda, Zuroshvili Lamara, \\ Margalitashvili Darejan, Azikuri Gela \\ Iakob Gogebashvili State University, Telavi
}

\begin{abstract}
For in-depth study of the peculiarities of the etiological and epizootic processes of gastrointestinal infections in sheep, we conducted a study to determine the role of conditional-pathogenic microorganisms in this pathology. A study of the prevalence and frequency of intestinal infections in lambs on farms in the Kakheti region has shown that this pathology is very common and harms the region's livestock. During the study of pathological material of fallen lambs and aborted fetuses, 365 cultures were isolated, of which 182 cultures belonged to the genus Escherichia, 143 Salmonella, 28 - Klebsiella, 4 - Streptococcus, 1 - Proteus and 7 cultures Diplococcus. Bacteria from the Enterobacteriaceae family has been found to play an important role in the development of gastro-intestinal diseases in lambs, accounting for approximately $97 \%$ of isolated cultures, of which Escherichia and Salmonella predominate, 51.0\% and 39.1\%.

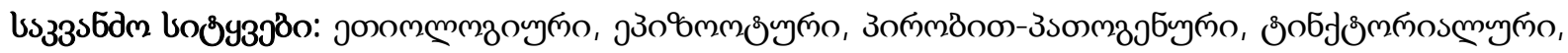

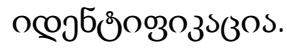

Keywords: etiological, epizootic, conditional-pathogenic, tinctorial, identification. 